Polymer Journal, Vol. 39, No. 2, pp. 147-154 (2007)

(C) 2006 The Society of Polymer Science, Japan

\title{
Calorimetric and High Pressure Fluorescence Studies of the Salt Effects on Thermolysin
}

\author{
Moto Kitayaki, Tomoko TAda, Tomohiro Matsumoto, and Shigeru KunUgi ${ }^{\dagger}$ \\ Department of Biomolecular Engineering, Graduate School of Science and Technology, \\ Kyoto Institute of Technology, Matsugasaki-Hashigamichou 1, Sakyo-ku, Kyoto 606-8585, Japan
}

(Received August 31, 2006; Accepted November 7, 2006; Published December 21, 2006)

\begin{abstract}
The relationship of the salt-activation of thermolysin and the thermodynamic properties was investigated by using DSC and high-pressure spectrofluorometry. As previously reported [Holmquist and Vallee, Biochemistry, 15, 101 (1976), Fukuda and Kunugi, Biocatalysis, 2, 225 (1989)], 1:1 salts such as $\mathrm{Na}^{+}$and $\mathrm{K}^{+}$with $\mathrm{Cl}^{-} \mathrm{or} \mathrm{Br}^{-}$ showed monotonous increase in the activity, and the rankings of rate increase at $2 \mathrm{M}$ were $\mathrm{Na}^{+} \approx \mathrm{K}^{+}>\mathrm{Ca}^{2+}>\mathrm{Mg}^{2+}$ and $\mathrm{Cl}^{-} \approx \mathrm{Br}^{-}>\mathrm{I}^{-} \approx \mathrm{SO}_{4}{ }^{2-}>\mathrm{SCN}^{-}$. In the presence of salt, thermolysin showed lower peak temperature in DSC, and the instability was in the order of $\mathrm{SCN}^{-}>\mathrm{I}^{-}>\mathrm{Br}^{-}>\mathrm{Cl}^{-}$and $\mathrm{Ca}^{2+}>\mathrm{Mg}^{2+}>\mathrm{Na}^{+}>\mathrm{K}^{+}$. By addition of $0.5 \mathrm{M} \mathrm{NaBr}$, the contour map of the peak intensity of thermolysin intrinsic fluorescence became much simpler, and the contour shifted to lower temperature. The $-\Delta V$ values of the transition decreased with increasing salt at lower concentration range, but then increased at higher concentration, especially at higher temperature. Thus $\Delta V$ became more negative with increasing temperature. These results are discussed with respect to the ion distribution among the lowand high-density water phases in the protein solution, and the surface charge, hydration, and flexibility of enzyme protein, especially at the transition state of the catalysis. [doi:10.1295/polymj.PJ2006106]

KEY WORDS Thermolysin / Salt Effects / High Pressure / Protein / Denaturation / Calorimetry /

Fluorescence /
\end{abstract}

Specific functions performed by protein is realized by its hierarchical structures. A change or a collapse of the higher-order structure results in a loss of the function. Thus stability of proteins and enzymes is the main concern of the researchers on proteins in various fields, from very fundamental to industrial or clinical applications. ${ }^{1-10}$ The term "denaturation" indicates the functional aspects, but, at the same time, it means structural changes. The relations between higher-order structures and the functions of proteins are usually studied by observing the influence of some physical and/or chemical factors, which affect the protein structure, upon the function, such as nonphysiological temperature, $\mathrm{pH}$, pressure, and various additives.

The coexistence of various salts, or electrolytes, also strongly affects the protein structure, ${ }^{11-17}$ through directly acting on the dissociating groups of the protein surface (shifting the actual $\mathrm{p} K_{\mathrm{a}}$ of the groups or shielding the inter-ionic interactions), or rather indirectly through changing the static and dynamic states of the surroundings or the hydrating waters. ${ }^{18-24}$

Thermolysin [EC.3.4.24.27], a metal protease from a moderately thermophilic bacteria (Bacillus thermoproteolyticus, Rokko) contains a catalytic $\mathrm{Zn}^{2+}$ ion and four $\mathrm{Ca}^{2+}$ in the protein. ${ }^{25-31}$ Thermolysin and its homologues are know to be strongly affected by the coexistence of inert salt: solubilization ${ }^{27}$ and acti- vation. ${ }^{32}$ This enzyme is also activated by application of high hydrostatic pressure. ${ }^{33,34}$ Kunugi et al. reported the cooperative effects of inert salt and high hydrostatic pressure,,$^{35}$ on the catalytic activity and explained the results in terms of hydration changes caused by the two perturbation agents. However, there are few information on the structure-related properties of this enzyme in the presence of salt. ${ }^{36,37}$ In this report, we have examined the relationship of saltactivation of thermolysin and its changes in some thermodynamic properties, mainly by using differential calorimetry and high pressure spectrofluorometry.

\section{EXPERIMENTAL}

\section{Materials}

Thermolysin was purchased from Sigma (St. Louis, Mo. USA). N-Furylacryloyl-glycyl-leucineamide (FuaGly-LeuNH ${ }_{2}$ ), $\quad N$-furylacryloyl-glycyl-leucyl-alanine (Fua-Gly-Leu-Aa), and $N$-furylacryloyl-glycyl-phenylalanineamide (Fua-Gly-PheNH${ }_{2}$ ) were purchased from the Peptide Institute (Minoo, Japan) or Bachem AG (Bubendorf, Switzerland). Other chemicals such as Mes and Hepes buffers were of commercially available reagent grade obtained from Wako Pure Chemicals (Osaka, Japan) or Nacalai Tesque (Kyoto, Japan).

${ }^{\dagger}$ To whom correspondence should be addressed (Tel: +81-75-724-7003, Fax: +81-75-724-7100, E-mail: kunugi@kit.ac.jp). 


\section{Methods}

Absorbance The concentrations of thermolysin was determined by UV-absorbance spectroscopy and by kinetic assay under our standard conditions (pH 6.5, [50 mM Hepes/NaOH], $10 \mathrm{mM} \mathrm{CaCl}_{2}, 2 \%$ $\mathrm{Me}_{2} \mathrm{SO}$, and $\left.100 \mathrm{mM} \mathrm{KBr}\right)^{38,39}$ against a dipeptide substrate, Fua-Gly-LeuNH$H_{2}$. The steady state kinetics and protein absorbance measurements were performed using an ultraviolet/visible spectrophotometer U2200 (Shimadzu: Kyoto, Japan). For hydrolytic reactions, the absorbance decrease in the furylacryloylpeptides following cleavage of the peptide bond adjacent to the acylated amino acid was monitored at $320-340 \mathrm{~nm}$. The apparent second-order rate constant $\left(k_{\text {cat }} / K_{\mathrm{m}(\mathrm{app})}\right.$ : apparent specificity constant $\left.{ }^{40}\right)$ was measured at pH $7.0(10 \mathrm{mM}$ Hepes/NaOH] $)$ and calculated from the initial velocity under the pseudofirst-order rate conditions with low substrate concentrations, within less than $5 \%$ conversion.

The 4th derivative absorbance analysis was evaluated by the shift-method, ${ }^{41,42}$ by using a singlebeam spectrophotometer (Multispec 1500, Shimadzu), equipped with an optical cell with two sapphire windows containing a quartz inner optical cell (diameter $=10 \mathrm{~mm})$. Sample solution temperature in the cell was detected by a Pt resistance thermometer and controlled by a Peltier-type thermoregulator.

Fluorescence Fluorescence spectra were measured on a spectrofluorometer (RF-5300, Shimadzu Co., Kyoto, Japan). Fluorescence under high pressure was monitored in a quartz inner optical cell (diameter = $10 \mathrm{~mm}$ ) settled in an optical high pressure vessel with three sapphire windows (TERAMECS Co. Kyoto, Japan). The whole vessel was located in the sample chamber of a spectrofluorometer. The external pressure was applied with a high-pressure hand pump equipped with an intensifier (ratio 8.5:1) (Teramecs); the pressure medium was deionized water, and was monitored by a Bourdon tube-type pressure gauge. Thermostated water was circulating through the vessel block and the temperature of water inside the vessel was detected by a $\mathrm{Cu}$-constantan thermocouple.

Differential Scanning Calorimetry (DSC) DSC was performed by a high-sensitive DSC meter, NanoDSC II Model 6100 (Calorimetric Science Co., Lindon, USA). About $0.3 \mathrm{~mL}$ of an aqueous solution of thermolysin was introduced to the sample tube of the apparatus and the temperature-scanning rate was usually $1 \mathrm{~K} / \mathrm{min}$. The scanning rate effects on the obtained thermodynamic parameters were preliminary tested and checked. Although thermal denaturation of thermolysin is an irreversible process and the obtained thermogram was reported to be scanningrate-dependent, ${ }^{43} 1 \mathrm{~K} / \mathrm{min}$ or slower scanning gave practically no difference under our experimental con- ditions. The approximate van't Hoff enthalpy $\left(\Delta H^{\mathrm{vH}}\right)$ was calculated with the following equation. ${ }^{44}$

$$
\Delta H^{\mathrm{vH}}=4 R T_{\mathrm{t}}^{2}\left(C_{p}^{\max } / \Delta H\right)
$$

where $T_{\mathrm{t}}, C_{p}{ }^{\max }$ and $\Delta H$ are the peak temperature, maximum $C_{p}$, and enthalpy change of transition, as integrated from the thermogram, respectively. The cooperative number $(n)$ is the ratio of $\Delta H$ and $\Delta H^{\mathrm{vH}}$, which indicates the (average) number of cooperative units or domains in one protein molecule.

\section{RESULTS}

\section{Salt Activation}

Thermolysin activity is strongly affected by the coexistence of inert salt. The previous study by our

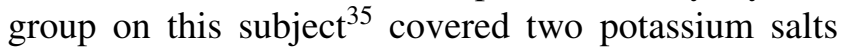
of monovalent anion $\left(\mathrm{Br}^{-}\right.$and $\left.\mathrm{Cl}^{-}\right)$, two chloride salts of divalent cation $\left(\mathrm{Ca}^{2+}\right.$ and $\left.\mathrm{Mg}^{2+}\right)$, and two sulfate salts $\left(\mathrm{K}^{+}\right.$and $\left.\mathrm{Na}^{+}\right)$. As the first stage of the present study, we have added four sodium salts $\left(\mathrm{Cl}^{-}, \mathrm{Br}^{-}\right.$, $\mathrm{I}^{-}$, and $\left.\mathrm{SCN}^{-}\right)$, and two bromide salts of divalent cations $\left(\mathrm{Ca}^{2+}\right.$ and $\left.\mathrm{Mg}^{2+}\right)$ to be examined for salt-activation ability. Figure 1 shows the result of the effects of these salts on the apparent specificity constant of thermolysin by using Fua-Gly-PheNH $\mathrm{N}_{2}$ as the substrate. The previously reported results ${ }^{35}$ on six mineral salts are re-plotted for the comparison. The 1:1 salts of $\mathrm{Na}^{+}$and $\mathrm{K}^{+}$with $\mathrm{Cl}^{-}$or $\mathrm{Br}^{-}$showed monotonous increase in relative activity within the range of applied concentration. Addition of $3 \mathrm{M} \mathrm{KCl}$ or $\mathrm{NaCl}$, e.g., accelerated the hydrolytic rate to more than 4-times. The salts of divalent cations $\left(\mathrm{Mg}^{2+}\right.$ and $\left.\mathrm{Ca}^{2+}\right)$ with $\mathrm{Cl}^{-}$or $\mathrm{Br}^{-}$showed rather concaved dependence and three of them showed maxima within the measured concentra-

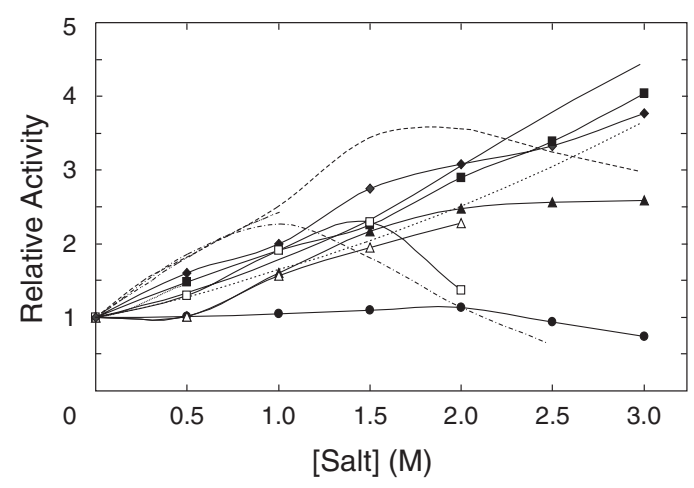

Figure 1. Effects of various salts on the apparent catalytic activity (specificity constant) of thermolysin. $\mathbf{\square}, \mathrm{NaCl} ; \bullet, \mathrm{NaBr}$; $\boldsymbol{\Lambda}, \mathrm{NaI} ; \bullet, \mathrm{NaSCN} ; \square, \mathrm{CaBr}_{2} ; \triangle, \mathrm{MgBr}_{2} . \longrightarrow \mathrm{KCl},-.-$ $\mathrm{KBr} ;----\mathrm{CaCl}_{2},-. \cdot--\mathrm{MgCl}_{2},-\cdot .-\cdot-\mathrm{K}_{2} \mathrm{SO}_{4}, \cdots \mathrm{Na}_{2} \mathrm{SO}_{4}$. [thermolysin] $=0.6 \mu \mathrm{M}, \quad\left[\right.$ Fua-Gly-PheNH $\left.{ }_{2}\right]=30 \mu \mathrm{M} . \quad \mathrm{pH}=7$ (Hepes/ $\mathrm{NaOH}$ ) and at $25^{\circ} \mathrm{C}$. Curves are arbitrary. $\mathrm{KCl}, \mathrm{KBr}$; $\mathrm{CaCl}_{2}, \mathrm{MgCl}_{2}, \mathrm{~K}_{2} \mathrm{SO}_{4}$, and $\mathrm{Na}_{2} \mathrm{SO}_{4}$ were reproduced from ref 35 . 


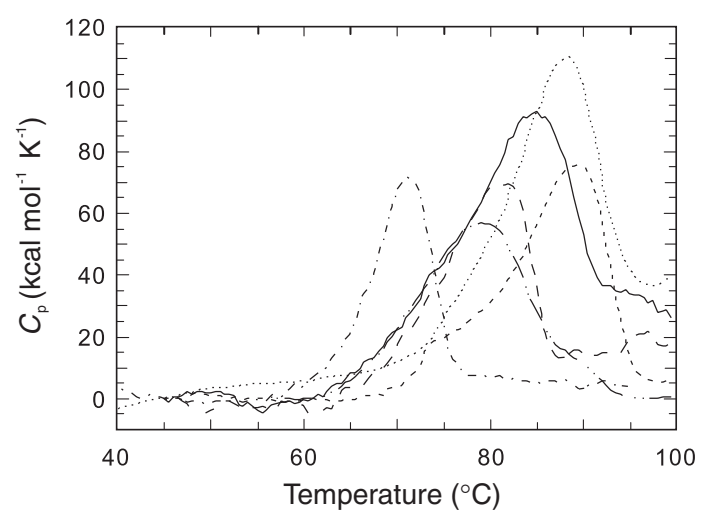

Figure 2. Examples of DSC thermograms in the presence of various salts. $-2 \mathrm{M} \mathrm{NaBr},-\ldots 2 \mathrm{M} \mathrm{NaCl},---2 \mathrm{M} \mathrm{NaI}$, -.-.- $2 \mathrm{M} \mathrm{NaSCN},-\cdot .-\cdot-1.5 \mathrm{M} \mathrm{Na}_{2} \mathrm{SO}_{4}, \cdots \cdots$ control $(0.02 \mathrm{M}$ $\mathrm{NaBr})$. [thermolysin] $=22 \mu \mathrm{M}, \mathrm{pH}=7$ (Hepes $/ \mathrm{NaOH})$.

tion range. NaI showed some plateau and $\mathrm{NaSCN}$ showed only very small activation leading to a disactivation at higher concentrations. The order of rate increase at $2 \mathrm{M}$ addition of each salt is: $\mathrm{CaCl}_{2}>$ $\mathrm{NaBr} \approx \mathrm{KCl}>\mathrm{NaCl}>\mathrm{KBr} \approx \mathrm{NaI}>\mathrm{MgBr}_{2}>$ $\mathrm{CaBr}_{2}>\mathrm{MgCl}_{2} \approx \mathrm{NaSCN}$. If we compare the results in terms of 'normality,' as in the original discussion for the protein precipitating ability of salts, ${ }^{45}$ the ranking at $2 \mathrm{~N}$ becomes $\mathrm{CaCl}_{2}>\mathrm{NaBr} \approx \mathrm{KCl}>\mathrm{NaCl} \approx$ $\mathrm{KBr}>\mathrm{NaI} \approx \mathrm{Na}_{2} \mathrm{SO}_{4}>\mathrm{MgCl}_{2}>\mathrm{CaBr}_{2}>\mathrm{MgBr}_{2}>$ $\mathrm{NaSCN}$. When cationic and anionic contributions are separately evaluated, the rankings are: $\mathrm{Na}^{+} \approx \mathrm{K}^{+}>$ $\mathrm{Ca}^{2+}>\mathrm{Mg}^{2+}$ for cations and $\mathrm{Cl}^{-} \approx \mathrm{Br}^{-}>\mathrm{I}^{-} \approx$ $\mathrm{SO}_{4}{ }^{2-}>\mathrm{SCN}^{-}$for anions.

\section{Thermal Stability}

Figure 2 shows the examples of DSC thermogram for thermolysin in the presence of various salts at $2 \mathrm{M}$ concentration. The thermodynamic parameters calculated from the obtained thermograms are listed in Table I. In the presence of salt, thermolysin showed generally lower stability (lower peak temperature, $T_{\mathrm{t}}$ ) than the control, except for $\mathrm{NaCl}$, which caused prac- tically no changes in the thermal stability. Instability was acquired in the order of $\mathrm{SCN}^{-}>\mathrm{I}^{-}>\mathrm{Br}^{-}>$ $\mathrm{Cl}^{-}$for anions and $\mathrm{Ca}^{2+}>\mathrm{Mg}^{2+}>\mathrm{Na}^{+}>\mathrm{K}^{+}$for cations.

For $\mathrm{NaCl}, \mathrm{NaBr}$, and $\mathrm{CaBr}_{2}$, the salt concentration dependence of $T_{\mathrm{t}}, \Delta H, \Delta S$, and $\Delta C_{p}$ was investigated and the results are shown in Figure 3. As mentioned above, $\mathrm{NaCl}$ caused almost no changes in $T_{\mathrm{t}}$, but $\Delta H$ increased with the concentration of $\mathrm{NaCl}$ and $\Delta S$ compensated this change. $\mathrm{NaBr}$ slightly decreased $T_{\mathrm{t}}$, almost linearly with its concentration, and the changes in $\Delta H$ (and $\Delta S$ ) were rather small. With addition of small amount of $\mathrm{CaBr}_{2}$, while the changes in $T_{\mathrm{t}}$ were not large, $\Delta H$ increased sensitively, and then further addition of this salt decreased both $T_{\mathrm{t}}$ and $\Delta H$, giving concaved feature for $\Delta H$. For all three slats, $\Delta C_{p}$ increased with increasing salt concentration. Certain increase was observed at rather low concentrations of the salts, and the change for $\mathrm{CaCl}_{2}$ at higher concentration was very large. $\mathrm{NaBr}$ caused the least $\Delta C_{p}$ change among the three.

\section{Effects of Salt on Intrinsic Fluorescence and 4th} Derivative UV Absorbance Spectra

The intrinsic fluorescence of thermolysin changed with the addition of salt. Figure 4a shows the fluorescence spectra in the presence of $2 \mathrm{M}$ Na salt. Some salt such as NaSCN increased the intensity, but no evident shift in the peak wavelength was observed.

Changes in the chromophore environment of proteins can also be detected by measuring 4th derivative UV absorbance spectra. ${ }^{46,47}$ Figure $4 \mathrm{~b}$ shows the $\mathrm{NaBr}$ concentration dependence of the 4 th derivative UV absorbance spectrum measured at $25^{\circ} \mathrm{C}$. Although the fluorescence intensity did not show remarkable changes for $\mathrm{NaBr}$, the peak intensities of this spectrum showed slight increase with additions of $\mathrm{NaBr}$, but practically no peak-shifts were observed up to $1 \mathrm{M}$.

4th derivative UV spectra within this wavelength range mainly reflect Trp and Tyr residues. There are

Table I. Thermodynamic parameters of thermal transition of thermolysin calculated from DSC data in the presence of various salts

\begin{tabular}{ccccccc}
\hline $\begin{array}{c}\text { Added } \\
\text { Salt }\end{array}$ & $\begin{array}{c}T_{\mathrm{t}} \\
/{ }^{\circ} \mathrm{C}\end{array}$ & $\begin{array}{c}\Delta H_{\text {cal }} \\
/ \mathrm{kJ} \mathrm{mol}^{-1}\end{array}$ & $\begin{array}{c}\Delta S \\
/ \mathrm{kJ} \mathrm{mol}^{-1} \mathrm{~K}^{-1}\end{array}$ & $\begin{array}{c}C_{p(\mathrm{Tt})} \\
/ \mathrm{kJ} \mathrm{mol}^{-1} \mathrm{~K}^{-1}\end{array}$ & $\begin{array}{c}\Delta H^{\mathrm{vH}} \\
/ \mathrm{kJ} \mathrm{mol}^{-1}\end{array}$ & $\Delta H_{\text {cal }} / \Delta H^{\mathrm{vH}}$ \\
\hline $\mathrm{NaBr}$ & 83.5 & 993 & 2.79 & 67.5 & 287 & 3.5 \\
$\mathrm{NaI}$ & 80.5 & 755 & 2.14 & 63.8 & 351 & 2.2 \\
$\mathrm{NaCl}$ & 88.5 & 960 & 2.66 & 68.4 & 309 & 3.1 \\
$\mathrm{NaSCN}$ & 71.0 & 563 & 1.64 & 65.9 & 461 & 1.2 \\
$\mathrm{Na}_{2} \mathrm{SO}_{4}$ & 79.0 & 843 & 2.39 & 56.5 & 276 & 3.1 \\
$\mathrm{KBr}$ & 84.5 & 975 & 2.73 & 55.5 & 242 & 4.0 \\
$\mathrm{CaBr}_{2}$ & 67.0 & 972 & 2.86 & 72.2 & 286 & 3.4 \\
$\mathrm{MgBr}_{2}$ & 74.5 & 1125 & 3.24 & 101.1 & 361 & 3.1 \\
none & 88.1 & 977 & 2.70 & 83.3 & 370 & 2.6 \\
\hline
\end{tabular}

${ }^{*}[$ salt $]=2 \mathrm{M}$, except for $\mathrm{Na}_{2} \mathrm{SO}_{4}(1.5 \mathrm{M})$. 

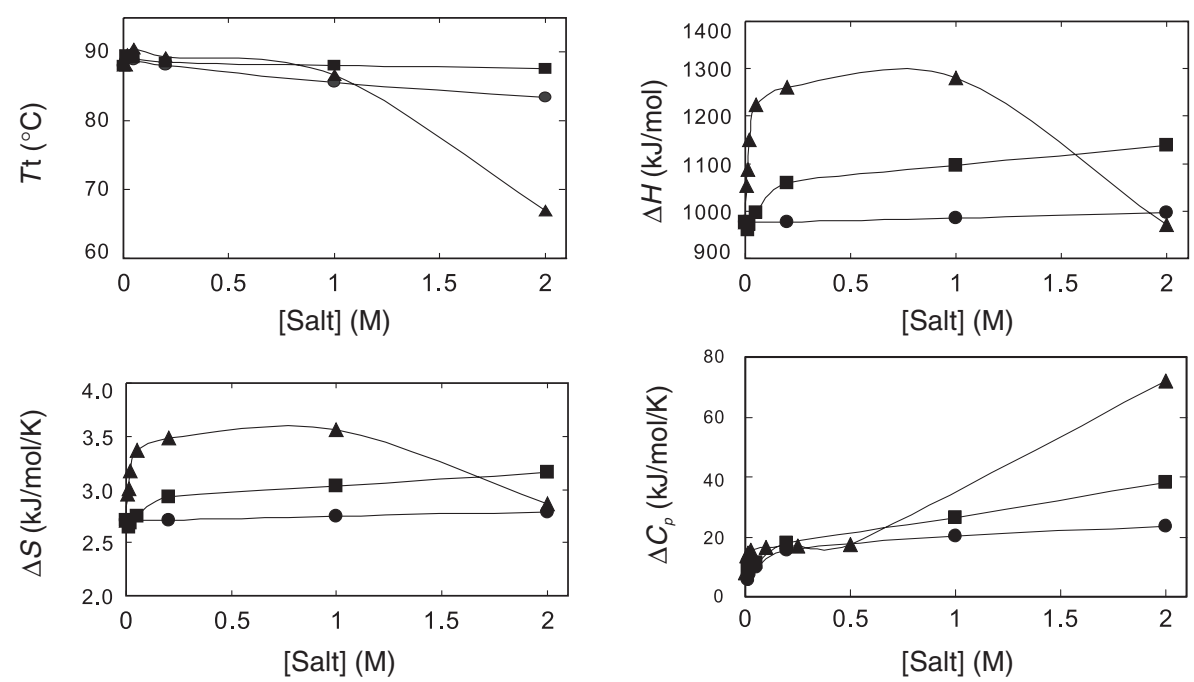

Figure 3. Effects of the salt concentration on $T_{\mathrm{t}}, \Delta H\left(\Delta H_{\text {cal }}\right), \Delta S$, and $\Delta C_{p}$ values for $\mathrm{NaBr}(\bullet), \mathrm{NaCl}(\mathbf{\square})$ and $\mathrm{CaBr} 2(\mathbf{\Delta})$. [thermolysin] $=22 \mu \mathrm{M}, \mathrm{pH}=7$ (Hepes $/ \mathrm{NaOH})$. Curves are arbitrary.
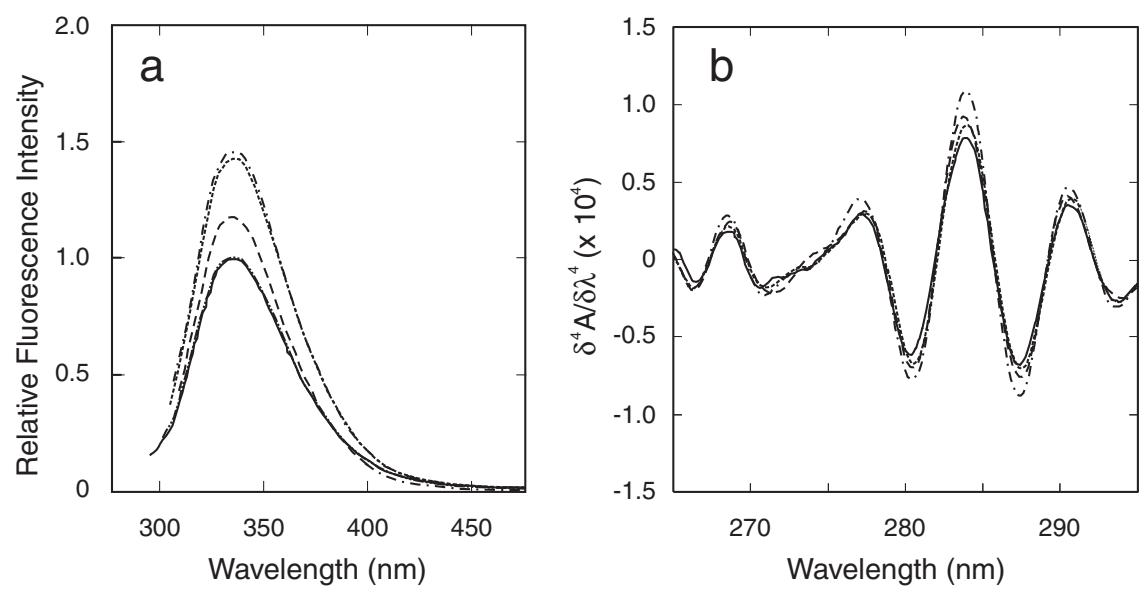

Figure 4. Effects of salt on the intrinsic fluorescence (a) and the 4th derivative UV spectrum (b) of thermolysin. $\mathrm{a} ;-2 \mathrm{M} \mathrm{NaBr}$,

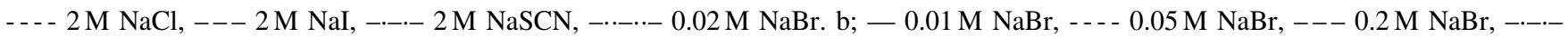
$1 \mathrm{M} \mathrm{NaBr}$. [thermolysin] $=7 \mu \mathrm{M}, \mathrm{pH} 7(10 \mathrm{mM}$ HEPES $/ \mathrm{NaOH})$, at $25^{\circ} \mathrm{C}$.

three $\operatorname{Trp}$ and 28 Tyr residues in thermolysin. ${ }^{48}$ Trp residues are mainly detected at wavelengths higher than $290 \mathrm{~nm}$ and Tyr residues are mainly reflected by changes in wavelengths lower than $280 \mathrm{~nm}$. To cancel out the effects of the solvent refractive index and others, the amplitude difference of adjacent maximum and minimum peaks was normalized by the corresponding change in free Tyr and Trp solutions, and an approximate $30 \%$ increase in peak intensity was observed at $1 \mathrm{M} \mathrm{NaBr}$. Thus, for both residues, some slight changes in the local chromophore environment towards lower dielectric constants ${ }^{41}$ (apolar environment) seemed to occur under these conditions.

\section{Pressure Dependence of Intrinsic Fluorescence}

In order to study the pressure-stability of thermolysin in the presence of salt $(\mathrm{NaBr}, \mathrm{NaCl})$, the intrinsic fluorescence spectrum was measured with excitation at $290 \mathrm{~nm}$ under various pressures (every $50 \mathrm{MPa}$ from $0.1 \mathrm{MPa}$ to $400 \mathrm{MPa}$ ) and temperatures (every $5^{\circ} \mathrm{C}$ from $0^{\circ} \mathrm{C}$ to $40^{\circ} \mathrm{C}$ ). The fluorescence peak wavelength red-shifted (Figure 5a) and the peak intensity decreased (Figure $5 \mathrm{~b}$ ) with increasing pressure. The results for $0.5 \mathrm{M} \mathrm{NaBr}$ are shown in Figure 6a, as a contour map of the peak intensity. The previously published result for $0.02 \mathrm{M} \mathrm{NaBr}^{49}$ is re-plotted in Figure $6 \mathrm{~b}$, for comparison. At lower concentrations of $\mathrm{NaBr}$, thermolysin showed rather circular contours and contours showing positive $\mathrm{d} P / \mathrm{d} T$ values were observed in the range of low temperatures and high pressures, which was interpreted as the participation of a pressure-assisted low-temperature (cold) denaturation of the protein. ${ }^{50}$ At higher concentrations of $\mathrm{NaBr}$ $(0.5 \mathrm{M})$, however, the contours became rather simple and showed mostly negative $\mathrm{d} P / \mathrm{d} T$ values in the measured range of pressure and temperature, as if 

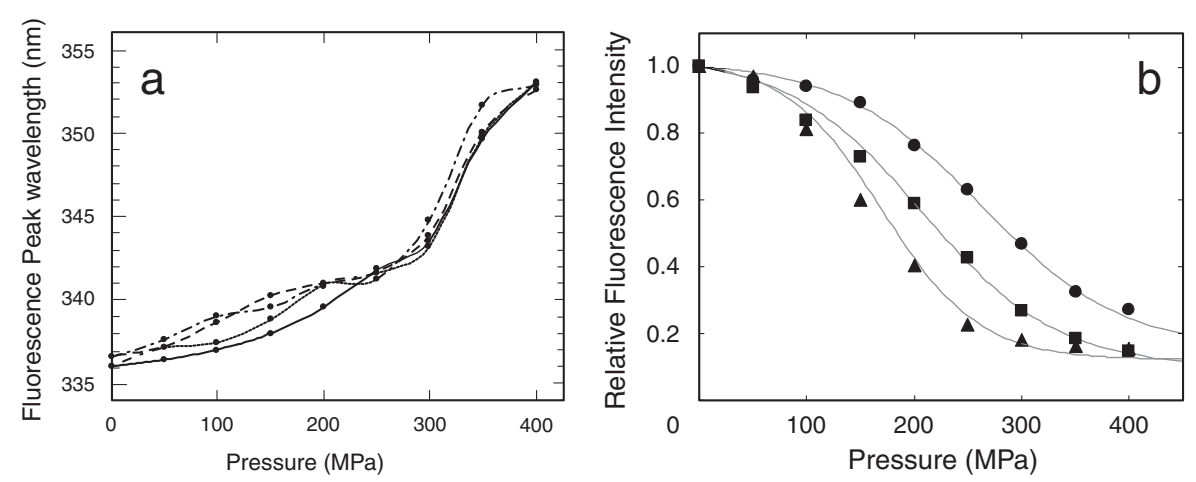

Figure 5. Effects of pressure on the intrinsic fluorescence peak wavelength (a) and the fluorescence peak intensity (b) of thermolysin. a; $-0.01 \mathrm{M} \mathrm{NaBr},---0.2 \mathrm{M} \mathrm{NaBr},---0.5 \mathrm{M} \mathrm{NaBr},-.--1 \mathrm{M} \mathrm{NaBr}$, at $25^{\circ} \mathrm{C}$. Curves are arbitrary. b; $\boldsymbol{\Delta},[\mathrm{NaBr}]=0.01 \mathrm{M}$ at $25^{\circ} \mathrm{C}$; - $[\mathrm{NaBr}]=1 \mathrm{M}$ at $25^{\circ} \mathrm{C} ; \mathbf{\square},[\mathrm{NaBr}]=1 \mathrm{M}$ at $45^{\circ} \mathrm{C}$. Curves are regressed on the basis of eq 2. [thermolysin] $=6 \mu \mathrm{M}$. $\lambda_{\mathrm{ex}}=290 \mathrm{~nm}$, pH $7.0(10 \mathrm{mM}$ HEPES/NaOH$)$.

the contour of the lower $\mathrm{NaBr}$ concentration shifted towards the lower temperature.

The obtained pressure dependence of the intensity data was analyzed by assuming a simple two state transition model (between the native $(\mathrm{N})$ and the denatured (D) states) using the following equation, and the $\Delta V$ values of the transition were evaluated at each temperature.

$$
\begin{gathered}
{[\mathrm{D}] /([\mathrm{D}]+[\mathrm{N}])=\left\{\exp \left[\left(\Delta G_{(0.1 \mathrm{~Pa})}-P \Delta V\right) / R T\right]\right\}} \\
/\left\{1+\exp \left[\left(\Delta G_{(0.1 \mathrm{~Pa})}-P \Delta V\right) / R T\right]\right\}
\end{gathered}
$$

As some examples curves were shown in Figure 5b, the obtained data were well regressed by this equation. Data shown in Figure 7a highlight the salt concentration dependence of the obtained $\Delta V$ values. More or less $\Delta V$ decreased at lower ion concentrations, and then increased at higher concentrations at higher temperatures. Thus, curves were concave. The temperature dependence of $\Delta V$ for $0.5 \mathrm{M} \mathrm{NaBr}$ is shown in Figure $7 \mathrm{~b}$. Since the higher pressure causes denaturation, $\Delta V$ is always a negative value, and it becomes more negative with increasing temperature. Thus, the half-denaturation pressure was below $100 \mathrm{MPa}$ above $50^{\circ} \mathrm{C}$, while it was higher than 250 $\mathrm{MPa}$ at temperatures below $20^{\circ} \mathrm{C}$. The slope of the curve, indicating $\partial \Delta V / \partial \mathrm{T}=$ absolute expansivity $(\Delta \alpha)$, was about $-0.5\left(\mathrm{~mL} \mathrm{~mol}^{-1} \mathrm{~K}^{-1}\right)$ at lower temperatures and approximated $-2\left(\mathrm{~mL} \mathrm{~mol}^{-1} \mathrm{~K}^{-1}\right)$ at higher temperatures.

\section{DISCUSSION}

Effects from the addition of salts on the structure and the function of proteins, including enzymes, have been studied for over 100 years, since the pioneering work by Hofmeister ${ }^{45}$ concerning the ranking of the salting-out effect. ${ }^{11-17,24}$ Even though in recent years, a number of excellent reviews have been published, a full understanding of the events surrounding (salt effects or salting in or out) has yet to be completed.

Very simply, protein precipitation by adding (increasing concentrations of) salt (salting out) is explained by the strong hydration of ions near the protein surface which removes water from solvated protein and increases the effective concentration of the protein. Thus the greatest effect is given by the most strongly hydrated ions. On the contrary, protein salting in, an increase in protein solubility by adding lower concentrations of salt, can be explained as resulting from counter ion binding on protein and the higher protein net charge, in which the greatest effect is given by the most weakly hydrated ions.

The events are far more complicated, however, and various researchers have revealed that the effects from salt addition on solvated protein depend on several interactions and factors such as; hydration of ions and proteins, water dipole, electrostatic interactions, internal pressure, and van der Waals forces etc. ${ }^{17}$ The effectiveness and, in some cases, even the direction of the effects are very much dependent on the property of the individual protein.

A useful and schematic understanding of salt effects is given by considering the partitioning of ionic species into two water phases ${ }^{24}$ depending on the density of water caused by the effects on water structure and clathrates. The water near the protein boundary has a lower density (low-density water: LDW) than the bulk water (high-density water: HDW), and the hydration strength and valence ions affect the partitioning of ions into these two phases.

Strongly hydrating ions, both cations and anions, are excluded from the LDW phase and weakly hydrating ions accumulate in the LDW. Contributions that stabilize the protein structure are large for strong hydrating anions and weak hydration cations, while an inverse combination exerts a destabilizing effect. For many salts, the addition of a lower concentration leads to a salting-in effect via ionic strength, but higher con- 

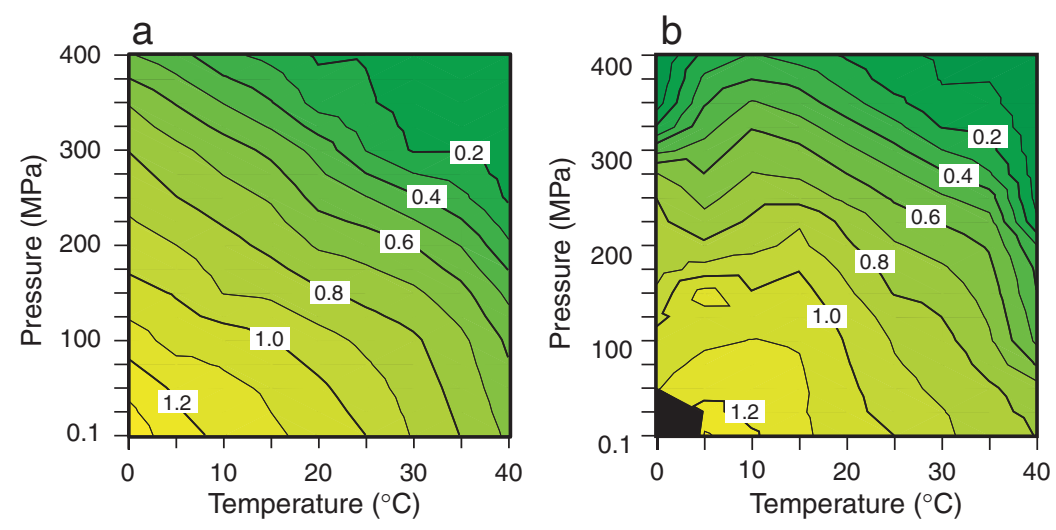

Figure 6. Pressure and temperature dependence of the fluorescence peak intensity of thermolysin in the presence of $0.5 \mathrm{M} \mathrm{NaBr}$ (a) compared with that at $0.02 \mathrm{M} \mathrm{NaBr}$ (b). [thermolysin] $=6 \mu \mathrm{M}$ (a) or $7.5 \mu \mathrm{M}$ (b). $\lambda_{\mathrm{ex}}=290 \mathrm{~nm}$, pH $7.0(10 \mathrm{mM} \mathrm{HEPES} / \mathrm{NaOH})$. $\mathrm{b}$, replotted using previously published data (ref 49). Numbers in the figure indicate the relative fluorescence peak intensity $(1.0$ at $25^{\circ} \mathrm{C}$ and $\left.0.1 \mathrm{MPa}\right)$.
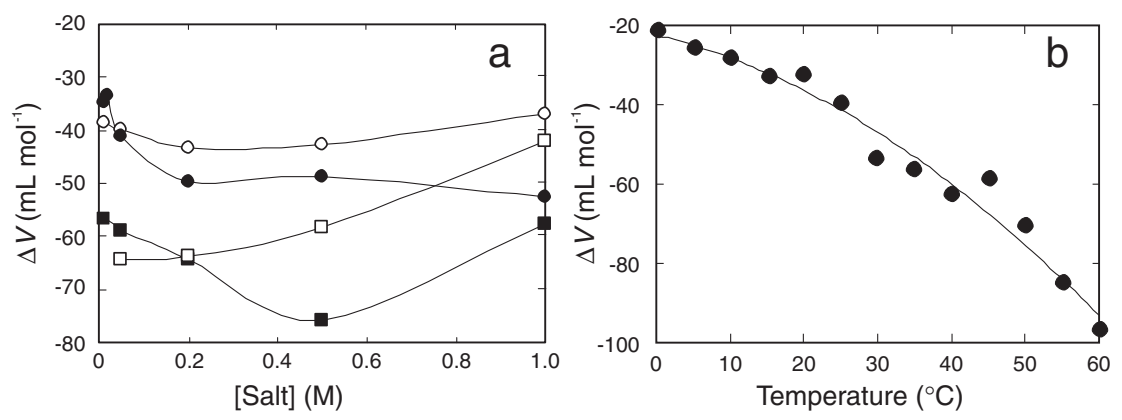

Figure 7. The salt concentration dependence of $\Delta V$ values at 25 and $45^{\circ} \mathrm{C}$ (a) and the temperature dependence of $\Delta V$ values in the presence of $\mathrm{NaBr}(0.5 \mathrm{M})$ (b) for thermolysin transitions. a; $\bigcirc \mathrm{NaCl}$ at $25^{\circ} \mathrm{C}, \bullet \mathrm{NaBr}$ at $25^{\circ} \mathrm{C}, \square \mathrm{NaCl}$ at $45^{\circ} \mathrm{C}$, $\square \mathrm{NaBr}$ at $45^{\circ} \mathrm{C}$. Curves are arbitrary. $\mathrm{b}$; The curve was regressed on a basis of 2 nd polynominal equation. [thermolysin] $=6 \mu \mathrm{M}$. $\lambda_{\mathrm{ex}}=290 \mathrm{~nm}, \mathrm{pH} 7.0(10 \mathrm{mM}$ HEPES/NaOH).

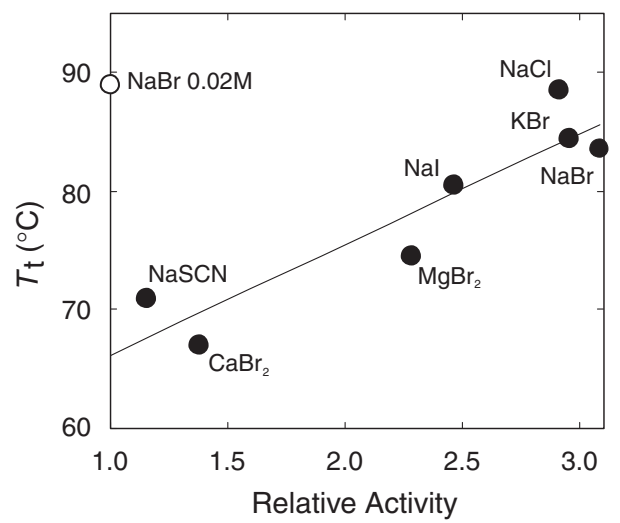

Figure 8. The correlation of salt effects on $T_{\mathrm{t}}\left({ }^{\circ} \mathrm{C}\right)$ and relative activities at $[$ salt $]=2 \mathrm{M}$.

centrations clearly reveal ion-specificities. For ions partitioned in LDW, rather specific interactions with dissociative or polar residues and with the peptide groups on the protein must also be considered.

Besides the Hofmeister series, several physicochemical properties, such as ionic volume, the Jones-

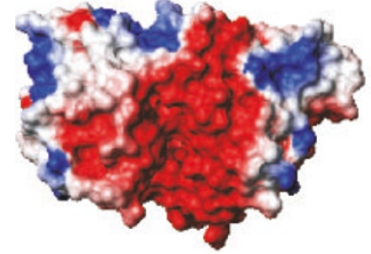

$$
[\mathrm{NaBr}]=0.01 \mathrm{M}
$$

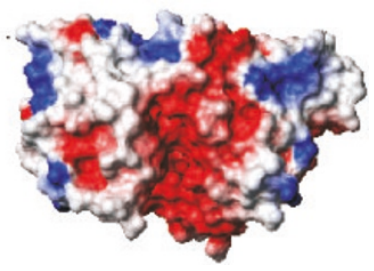

$[\mathrm{NaBr}]=1 \mathrm{M}$
Figure 9. The electrostatic potential of the thermolysin surface in the presence of $0.01 \mathrm{M} \mathrm{NaBr}$ (a) and $1 \mathrm{M} \mathrm{NaBr}$ (b). Figures were prepared with the program MOLMOL ${ }^{53}$ (a program for display and analysis of macromolecular structures) with the published structure of thermolysin ${ }^{54}$ (PDB code 1TLX). Color changes from blue (most positive) through white (neutral) to red (most negative).

Dole B-coefficient of water viscosity, the entropy of the ionic hydration, the surface tension etc have been used to explain the effects of ions on water structure and protein solubility. ${ }^{18-24}$ In most of these properties, $\mathrm{Na}^{+}$and $\mathrm{Cl}^{-}$are positioned in the middle of the sequence. In other words, $\mathrm{NaCl}$ has somehow neutral 
or intermediate effects; $\mathrm{Na}^{+}$and $\mathrm{Cl}^{-}$being borderline on the strong and weak sides of ionic hydration. With the exception of the sulfate anion, the ions examined in this study are medium to strong hydrating cations and medium to weak hydrating anions, and rankings for the catalytic activation and stability of thermolysin observed are consistent with the Hofmeister series. Thus, when the acceleration factors at $2 \mathrm{M}$ salt concentrations were plotted against the apparent $T_{\mathrm{t}}$ values, they exhibited a positive correlation $\left(\mathrm{R}^{2}=\right.$ 0.84), as shown in Figure 8. The salt causing a larger instability showed a lower acceleration at $2 \mathrm{M}$ concentrations, although the control (acceleration factor $=1$ ) did not fall on the correlation line.

Salt effects on the catalytic activity of thermolysin and related metal proteases were first reported by Holmquist and Vallee. ${ }^{32}$ Fukuda and Kunugi reported that the catalytic activity of these enzymes increased upon an increase in high hydrostatic pressure of 100$200 \mathrm{MPa},{ }^{33}$ and the authors clarified that the salt effects and pressure seemed to be additive or cooperative. ${ }^{35}$ The aforementioned results were commonly explained by assuming that the surface charges and polar groups newly exposed at the transient state of the catalytic pathway were stabilized by changes in the hydration state and counter ion binding., ${ }^{4,51}$

The solvent-accessible surface area of thermolysin is around $13000 \AA^{2}$, while $54 \%$ and $23 \%$ of the surface is covered by polar and ionic amino acids, respectively, as calculated on the basis of published data from the crystal structure and the solvent-accessible surface of each amino acid residue.

As for surface charges and enzyme activity, de Kreij et al. reported very interesting results on site specific mutations of a thermolysin-like protease. ${ }^{52}$ When N116, Q119, D150, and Q226 were replaced by $\mathrm{D}, \mathrm{R}, \mathrm{Q}$, and $\mathrm{R}$, respectively, with increasing +2 net charges in positions not directly affecting the enzyme catalytic site, mutants exhibited almost 4-times higher catalytic activity than the wild type enzyme. With additional site directed mutagenesis, though somehow specific to the individual position of the mutation, a higher activity was obtained by increasing positive net charges, indicating that the ionic and polar residues on this enzyme surface substantially contribute to the catalytic activity, through changes in the number of hydration and the flexibility of the protein, especially at the transition state.

The electrostatic potential of the thermolysin surface for different ionic concentrations is shown in Figure 9 for the case of $\mathrm{NaBr}$. The binding of monocation on free thermolysin at high ionic concentrations is evident. The neutralization of surface anions stabilizes the protein, and to a much higher extent in the transition state, which results in salt activation.
The effects of high pressure on the stability and function of proteins has attracted keen attention from various aspects. ${ }^{10,55-59}$ Leberman and Soper indicated that ions destroy the natural hydrogen bonding network of water and display effects similar to those seen when the temperature or pressure is increased. ${ }^{18}$ Actually ions lower the pressure required to form high pressure ice VII. ${ }^{60} 4 \mathrm{M} \mathrm{NaCl}$ equivalents with $140 \mathrm{MPa}$.

Since thermolysin is substantially activated by high hydrostatic pressures, activation volumes $\left(\Delta V^{\ddagger}\right)$ are large and negative, from $-50 \mathrm{~mL} \mathrm{~mol}^{-1}$ (at $10^{\circ} \mathrm{C}$ ) to close to $-100 \mathrm{~mL} \mathrm{~mol}^{-1}$ (at $45^{\circ} \mathrm{C}$ ). ${ }^{34}$ The aforementioned volume values are larger than those for the structural transition of the enzyme (Figure 7). On the contrary the activation enthalpy and the activation entropy are rather small $\left(5 \mathrm{~kJ} \mathrm{~mol}^{-1}\right.$ and -100 $\mathrm{J} \mathrm{mol}^{-1} \mathrm{~K}^{-1}$, respectively, at $25^{\circ} \mathrm{C} ;{ }^{33}$ around $5 \%$ of $\Delta H$ and $\Delta S$ of protein denaturation (Table I). The temperature dependence of the $\Delta V^{\ddagger}$ was almost linear, and the activation (absolute) expansivity is rather small $\left(\Delta \alpha^{\ddagger}=\left(\partial \Delta V^{\ddagger} / \partial T\right)_{\mathrm{P}}=c a . \quad-1 \mathrm{~mL} \mathrm{~mol}^{-1} \mathrm{~K}^{-1}\right.$ at $0.1 \mathrm{MPa}),{ }^{34}$ which corresponds to the absolute expansivity $(\Delta \alpha)$ of the protein $\left(-0.5\right.$ to $-2 \mathrm{~mL} \mathrm{~mol}^{-1}$ $\mathrm{K}^{-1}$ ). The pressure dependence of the fluorescence change of thermolysin was rationally reproduced by a simple equation such as eq 2 , and the pressure dependence of the apparent $\Delta V$ value $\left(=\Delta \beta_{\mathrm{T}}\right.$, isothermal compressibility) is small (within \pm 0.01 $\left.\mathrm{mL} \mathrm{mol}^{-1} \mathrm{MPa}^{-1}\right)$. This is in contrast to the rather large $\Delta \beta^{\ddagger}$ observed by the kinetic analysis of the catalytic reaction $\left(-0.5 \sim-1 \mathrm{~mL} \mathrm{~mol}^{-1} \mathrm{MPa}^{-1}\right){ }^{34} \mathrm{Ac}$ cording to statistical thermodynamics, ${ }^{61,62}$ the volume fluctuation of protein $\left(\delta V_{\mathrm{rms}}\right)$ is related to the protein volume $\left(V_{\mathrm{p}}\right)$ and $\beta_{\mathrm{T}}\left(\delta V_{\mathrm{rms}}=\left(k T V_{\mathrm{p}} \beta_{\mathrm{T}}\right)^{1 / 2}\right)$ and the transition state seems to have a much larger flexibility than the free enzyme. Recently, the importance of fluctuations and dynamics of enzymes in their catalytic process has been emphasized. ${ }^{58,63,64}$ The salt-activation of thermolysin seems to be accomplished by an increase in the flexibility of the transition state complex, through hydration changes and counter-ion binding. Both pressure- and salt-activation of thermolysin are substantially substrate-dependent, ${ }^{32,34}$ and therefore the dynamic properties of the transient state (activated) complex between the enzyme and the substrate seems to be highly influenced by hydration/ dehydration.

\section{REFERENCES}

1. M. P. Tombs, J. Appl. Biochem., 7, 3 (1985).

2. P. L. Privalov and S. J. Gill, Adv. Protein Chem., 39, 191 (1988).

3. C. N. Pace, Trends Biochem. Sci., 15, 14 (1990). 
4. G. N. Somero, Annu. Rev. Physiol., 57, 43 (1995).

5. R. Jaenicke, Naturwissenschaften, 83, 544 (1996).

6. F. M. Richards, Cell. Mol. Life Sci., 53, 790 (1997).

7. B. Lee and G. Vasmatzis, Curr. Opin. Biotechnol., 8, 423 (1997).

8. S. N. Timasheff, Adv. Protein Chem., 51, 355 (1998).

9. R. Jaenicke, J. Biotechnol., 79, 193 (2000).

10. C. Scharnagl, M. Reif, and J. Friedrich, Biochim. Biophys. Acta, 1749, 187 (2005).

11. K. D. Collins and M. W. Washabugh, Q. Rev. Biophys., 18, 323 (1985).

12. R. Leberman, FEBS Lett., 284, 293 (1991).

13. R. L. Baldwin, Biophys. J., 71, 2056 (1996).

14. Y. Zhou and C. K. Hall, Biopolymers, 38, 273 (1996).

15. M. G. Cacace, E. M. Landau, and J. J. Ramsden, Q. Rev. Biophys., 30, 241 (1997).

16. W. Kunz, P. Lo Nostro, and B. W. Ninham, Curr. Opin. Colloid Interface Sci., 9, 1 (2004).

17. P. K. Grover and R. L. Ryall, Chem. Rev., 105, 1 (2005).

18. R. Leberman and A. K. Soper, Nature, 378, 364 (1995).

19. A. A. Zavitsas, J. Phys. Chem. B, 105, 7805 (2001).

20. A. Neagu, M. Neagu, and A. Dér, Biophys. J., 81, 1285 (2001).

21. J. A. Schellman, Biophys. J., 85, 108 (2003).

22. R. Perez-Jimenez, R. Godoy-Ruiz, B. Ibarra-Molero, and J. M. Sanchez-Ruiz, Biophys. J., 86, 2414 (2004).

23. C. Scharnagl, M. Reif, and J. Friedrich, Biochim. Biophys. Acta, 1749, 187 (2005).

24. M. F. Chaplin, "Water structure and behavior," http:// www.lsbu.ac.uk/water/ accessed on 15 May 2006.

25. S. Endo, J. Ferment. Technol., 40, 346 (1962).

26. Y. Ohta, Y. Ogura, and A. Wada, J. Biol. Chem., 241, 5919 (1966).

27. S. A. Latt, B. Holmquist, and B. L. Vallee, Biochem. Biophys. Res. Commun., 37, 333 (1969).

28. H. Matsubara and J. Feder, Methods Enzymol., 3, 721 (1971).

29. R. S. Roche and G. Voordouw, CRC Crit. Rev. Biochem., 5, 1 (1978).

30. C. C. Hase and R. A. Finkelstein, Microbiol. Rev., 57, 823 (1993).

31. N. M. Hooper, FEBS Lett., 354, 1 (1994).

32. B. Holmquist and B. L. Vallee, Biochemistry, 15, 101 (1976).

33. M. Fukuda and S. Kunugi, Eur. J. Biochem., 142, 565 (1984).

34. S. Kunugi, M. Kitayaki, Y. Yanagi, N. Tanaka, R. Lange, and C. Balny, Eur. J. Biochem., 248, 567 (1997).

35. M. Fukuda and S. Kunugi, Biocatalysis, 2, 225 (1989).

36. J. F. Gaucher, M. Selkti, T. Prange, and A. Tomas, Acta Crystallogr., Sect. D: Biol. Crystallogr., 58, 2198 (2002).

37. M. Kamo, K. Nagata, and M. Tanokura, Acta Crystallogr., Sect. D: Biol. Crystallogr., 61, 710 (2005).
38. S. Kunugi, H. Hirohara, and N. Ise, Eur. J. Biochem., 124, 157 (1982).

39. M. Fukuda and S. Kunugi, Bull. Chem. Soc. Jpn., 57, 2965 (1984).

40. A. Fersht, "Structure and Mechanism in Protein Science -A Guide to Enzyme Catalysis and Protein Folding," W. H. Freeman Co., New York, 1999.

41. W. L. Butler, Methods Enzymol., 56, 501 (1979).

42. R. Lange, J. Frank, J.-L. Saldana, and C. Balny, Eur. Biophys. J., 24, 277 (1996).

43. J. M. Sanchez-Ruiz, J. L. Lopez-Lacomba, M. Cortijo, and P. L. Mateo, Biochemistry, 27, 1648 (1988).

44. P. L. Privalov and S. J. Gill, Adv. Protein Chem., 39, 191 (1979).

45. F. Hofmeister, Arch. Exp. Pathol. Pharmakol., 24, 247 (1888).

46. R. Lange, N. Bec, V. V. Mozhaev, and J. Frank, Eur. Biophys. J., 24, 284 (1996).

47. M. Ribo, J. Font, A. Benito, J. Torrent, R. Lange, and M. Vilanova, Biochim. Biophys. Acta, 1764, 461 (2006).

48. K. Titani, M. A. Hermodson, L. H. Ericsson, K. A. Walsh, and H. Neurath, Nature, New Biol., 238, 35 (1972).

49. H. Ikeuchi, S. Kunugi, and K. Oda, Eur. J. Biochem., 267, 979 (2000).

50. S. Kunugi and N. Tanaka, Biochim. Biophys. Acta, 1595, 329 (2002).

51. P. S. Low and G. N. Somero, Proc. Natl. Acad. Sci. U.S.A., 72, 3305 (1975).

52. A. de Kreij, B. van den Burg, G. Venema, G. Vriend, V. G. Eijsink, and J. E. Nielsen, J. Biol. Chem., 277, 15432 (2002).

53. R. Koradi, M. Billeter, and K. Wüthrich, J. Mol. Graphics Modell., 14, 51 (1996).

54. A. C. English, S. H. Done, L. S. Caves, C. R. Groom, and R. E. Hubbard, Proteins, 37, 628 (1999).

55. C. Balny, P. Masson, and K. Heremans, Biochim. Biophys. Acta, 1595, 3 (2002).

56. W. Dzwolak, M. Kato, and Y. Taniguchi, Biochim. Biophys. Acta, 1595, 131 (2002).

57. R. Winter and W. Dzwolak, Philos. Trans. R. Soc. London Ser. A. Math. Phys. Eng. Sci., 363, 537 (2005).

58. F. Meersman, L. Smeller, and K. Heremans, Biochim. Biophys. Acta, 1764, 346 (2006).

59. D. Knorr, V. Heinz, and R. Buckow, Biochim. Biophys. Acta, 1764, 619 (2006).

60. Y. Yoshimura, H. Mao, and R. J. Hemley, Chem. Phys. Lett., 400, 511 (2004).

61. A. Cooper, Proc. Natl. Acad. Sci. U.S.A., 73, 2740 (1976).

62. K. Gekko, Biochim. Biophys. Acta, 1595, 382 (2002).

63. P. K. Agarwal, J. Am. Chem. Soc., 127, 15248 (2005).

64. E. Z. Eisenmesser, O. Millet, W. Labeikovsky, D. M. Korzhnev, M. Wolf-Watz, D. A. Bosco, J. J. Skalicky, L. E. Kay, and D. Kern, Nature, 438, 117 (2005). 